\title{
PEMBINAAN KEGIATAN YOGA PADA WANITA MENOPAUSE HIPERTENSI DI LINGKUNGAN BENDEGA
}

\author{
Isviyanti ${ }^{1}$ ), I Gusti Agung Ayu Hari Triandini ${ }^{1}$, Ni Made Gita Gumangsari ${ }^{11}$, Diana Hidayati ${ }^{1}$, \\ Amelia Kandisa ${ }^{1)}$, Ni Luh Budi Astuti ${ }^{1}$, Adib Ahmad Shammakh') \\ 1)Program Studi D3 Kebidanan PSDKU Mataram, FIK, Universitas Bhakti Kencana, Mataram, Indonesia \\ Corresponding author : Isviyanti \\ E-mail : isviyanti@bku.ac.id
}

Diterima 10 Januari 2020, Disetujui 5 April 2020

\begin{abstract}
ABSTRAK
Hipertensi dapat dialami oleh semua kalangan usia, terutama pada usia paruh baya. Beberapa permasalahan yang dihadapi meliputi: 1 . Masih tingginya jumlah wanita menopause dengan hipertensi di lingkungan Bendega wilayah kerja Puskesmas Tanjung Karang. 2. Kurangnya informasi masalah pola hidup sehat yang dapat mencegah penyakit hipertensi. 3. Kurangnya kegiatan rutin atau aktivitas fisik yang dilakukan untuk penangulangan hipertensi pada wanita menopause 4. Belum adanya sosialisasi mengenai aktivitas fisik yoga dalam membantu menurunkan tekanan darah pada wanita menopause. Solusi yang dapat ditawarkan meliputi: 1. Pelatihan dan pendampingan aktivitas fisik yoga untuk mengurangi tekanan darah (hipertensi) pada wanita manupause. 2. Melakukan sosialisasi dan penyuluhan mengenai aktivitas fisik yoga dalam membantu menurunkan tekanan darah pada wanita menupause. 3. Pembagian booklet \& CD yoga sebagai panduan pelaksanaan yoga di rumah. Sasaran kegiatan pengabdian masyarakat adalah wanita menopause (umur 40-60 tahun), mampu melakukan gerakan yoga, hipertensi (tekanan darah sistolik $\geq 140 \mathrm{mmHg}$, diastolic $\geq 90 \mathrm{mmHg}$ ) dan tinggal di lingkungan Bendega. Kegiatan pengabdian ini menggunakan teknik penyuluhan tentang hipertensi dan yoga yaitu dengan menggunakan teknik ceramah, diskusi dan simulasi gerakan yoga dengan media sosialisasi berupa video dan booklet dilanjutkan dengan berlatih yoga bersama. Para peserta diberikan arahan tentang teknik gerakan dan manfaat dari gerakan-gerakan tersebut. Selain itu, mereka diajarkan pola hidup sehat untuk mencegah dan menanggulangi hipertensi. Dari kegiatan masyarakat yang telah dilakukan, menunjukkan bahwa hasil pengukuran tekanan darah sebelum latihan fisik yoga dan setelah latihan yoga mengalami perubahan. Dari 20 peserta kegiatan pengabdian masyarakat, rata-rata peserta mengalami penurunan sistol $20 \mathrm{mmHg}$ dan diastole $10 \mathrm{mmHg}$.
\end{abstract}

Kata kunci: hipertensi; menopause; yoga.

\begin{abstract}
Hypertension can be occurred in any age. Some of the problems faced include: 1 . The high number of menopausal women with hypertension in the Bendega 2. Lack of information on healthy lifestyle problems that can prevent hypertension. 3. Lack of routine activities or physical activities undertaken to overcome hypertension in menopausal women 4 . There is no socialization regarding physical activity of yoga in helping to reduce blood pressure in menopausal women. Solutions that can be offered include: 1. Training and mentoring physical activity of yoga to reduce blood pressure (hypertension) in postmenopausal women. 2. Socializing and counseling about the physical activity of yoga in helping to reduce blood pressure in menopausal women. 3. Distribution of yoga booklets \& CDs as a guide to implementing yoga at home. The target community service activities are menopausal women (aged 4060 years), able to do yoga movements, hypertension (systolic blood pressure $\geq 140 \mathrm{mmHg}$, diastolic $\geq$ $90 \mathrm{mmHg}$ ) and live in the Bendega environment. This dedication activity uses counseling techniques about hypertension and yoga that is by using lecture, discussion and yoga movement simulation techniques with media socialization in the form of videos and booklets followed by practicing yoga together. Participants are given direction about movement techniques and the benefits of these movements. In addition, they are taught a healthy lifestyle to prevent and treat hypertension. From the community activities that have been carried out, it shows that the results of blood pressure measurements before the physical exercise of yoga and after the practice of yoga have changed. From 20 participants of community service activities, the average participant experienced a decrease in systole of $20 \mathrm{mmHg}$ and diastole of $10 \mathrm{mmHg}$.
\end{abstract}

Keywords: hypertension; menopause; yoga. 


\section{PENDAHULUAN}

Seiring dengan bertambahnya umur, fungsi organ tubuh akan menunjukkan perubahan, salah satunya adalah perubahan fungsi organ reproduksi. Akhir kemampuan wanita untuk melakukan reproduksi dikenal dengan istilah menopause. Menopause merupakan kejadian yang normal pada seorang wanita. Wanita mengalami gejala menopause pada usia 40-an dan puncaknya terjadi pada usia 50 tahun. Menopause dipicu oleh perubahan hormon estrogen dan progesterone dalam tubuh. Hormon merupakan zat kimia yang dihasilkan oleh kelenjar-kelenjar tertentu tubuh, efek dari perubahan hormon yang terjadi dalam tubuh mempengaruhi kerja organ tubuh yang lain. Secara klinis menopause didiagnosa setelah 12 bulan dari sejak menstruasi terakhir (amenorhoe).

Kejadian menopause ini dapat mempengaruhi kualitas hidup wanita. Masalahmasalah kesehatan sering dialami pada usia menopause. Wanita yang sudah menopause sangat rentan terhadap timbulnya penyakit degeneratif (seperti jantung, hipertensi dan osteoporosis) karena pada usia menopause hormon yang berperan penting dalam pembentukan tubuh wanita dan mempersiapkan fungsi wanita (seperti untuk hamil dan melahirkan) sudah berhenti fungsi, sehingga pada usia menopause sering mengalami perasaan berdebar-debar, sulit tidur (insomnia), berkeringat dingin waktu malam dan emosi yang labil. Berhentinya fungsi hormon tersebut dapat menyebabkan penyempitan pembuluh darah yang berakibat meningkatkan tekanan darah.

Tekanan darah tinggi merupakan "Public Health Problem" yang terjadi di negara berkembang. Tekanan darah tinggi yang tidak segera ditangani akan menimbulkan faktor risiko berbagai jenis penyakit degeneratif. Adapun berbagai faktor risiko terjadinya tekanan darah tinggi yang dapat dikontrol yaitu pola makan dan gaya hidup. Perubahan pola makan tersebut adalahperubahan pola makan modern yang banyak terjadi di masyarakat seperti makanan tinggi lemak (seperti fast food dan junk food) dan perubahan gaya hidup yang serba otomatis sehingga menyebabkan kurangnya aktivitas fisik.

Aktivitas fisik yang kurang berpengaruh terhadap peningkatan tekanan darah, dimana kurangnya aktivitas fisik dapat meningkatkan frekuensi denyut jantung, sehingga menyebabkan jantung bekerja lebih keras dalam memompa darah yang pada akhirnya mengakibatkan naiknya tekanan darah. Adanya hubungan antara aktivitas fisik dengan tekanan darah, dimana aktivitas fisik yang rutin dan teratur akan melatih otot jantung dan menurunkan resistensi pembuluh darah perifer yang dapat menurunkan tekanan darah tinggi.

Berdasarkan Riset Kesehatan Dasar tahun 2018, prevalensi hipertensi terjadi peningkatan dari $25,8 \%$ pada tahun 2013 menjadi $34,1 \%$ pada tahun 2018. Wanita menopause yang terdiagnosa hipertensi dengan rentan umur 45-54 tahun sudah mencapai 45,3\%. Pada tingkat provinsi Nusa Tenggara Barat, bahwa prevalensi tekanan darah tinggi cukup tinggi sebesar $22,2 \%$. terjadinya kenaikan bisa bermacam-macam mulai dari wanita menopause merasa sudah sehat sampai yang sudah tidak mau datang berobat ke fasilitas kesehatan.

Dari tahun 2013 -2018 di Indonesia kasus tekanan darah tinggi masih memerlukan perhatian yang khusus. Mengingat tekanan darah tinggi yang tidak segera diatasi akan menimbulkan faktor risiko berbagai jenis penyakit degeneratif. Bidan berperan meningkatkan status kesehatan dan kualitas hidup pada wanita menopause. Menurut Word Health Organization (WHO) kualitas hidup (Quality of Life/QOL) adalah persepsi individu terhadap posisi mereka dalam kehidupan sebagai konteks budaya dan nilai dimana mereka hidup dalam hubungannya dengan tujuan hidup, harapan, standar dan perhatian.

Program prolanis yang telah dijalankan oleh pemerintah menggunakan senam aerobik sebagai salah satu usaha pengobatan nonfarmakologis yang dilaksanakan 1 minggu sekali menggunakan senam aerobik dengan ritmis 20-30 menit disebut sebagai senam jantung diabetes sehat dan senam muka. Senam muka adalah senam yang mengajarkan para peserta untuk mengerakkan bagian wajah seperti membuka mulut,memiringkan bibir dan sebagainya yang bertujuan agar mengurangi resiko terkenanya penyakit.

Selain aktivitas fisik senam aerobik, yoga juga dapat menjadi salah satu alternatif pengobatan holistik. keistimewaan yoga dapat menyatukan dari tubuh (body), pikiran (mind), jiwa (soul). Yoga merupakan latihan fisik yang memfokuskan pada latihan pernafasan. Yoga mengkombinasikan antara teknik bernafas, relaksasi dan meditasi serta latihan peregangan. Yoga di anjurkan pada penderita hipertensi, karena memiliki efek relaksasi yang dapat meningkatkan sirkulasi darah ke tubuh.

Salah satu aspek pentingnya adalah meditasi yang menimbulkan beberapa perubahan fisiologis berupa respon relaksasi. Hasil penelitian dari beberapa peneliti dalam jurnal Medical Hypoteses menemukan adanya 
keterkaitan atau pengaruh yoga terhadap penurunan stres. Menurut Streeter Professor Psikiatri dari Boston University School of Medicine mengatakan bahwa gerakan yoga dapat memperbaiki ketidakseimbangan hormon dan ketidakseimbangan sistem - sistem persarafan.

Yoga juga menstimulasi pengeluaran hormon endorfin. Endorphin adalah neuropeptide yang dihasilkan tubuh pada saat relaks/tenang. Endorphin dihailkan di otak dan susunan syaraf tulang belakang. Hormon ini dapat berfungsi sebagai obat penenang alami yang diproduksi otak yang melahirkan rasa nyaman dan meningkatkan kadar endorphin dalam tubuh untuk mengurangi tekanan darah tinggi. Olahraga terbukti dapat meningkatkan kadar endorphin empat sampai lima kali dalam darah. Sehingga, semakin banyak melakukan yoga maka akan semakin tinggi pula kadar bendorphin. Ketika seseorang melakukan yoga, maka $\beta$-endorphin akan keluar dan ditangkap oleh reseptor di dalam hipothalamus dan sistem limbik yang berfungsi untuk mengatur emosi. Peningkatan $\beta$-endorphin terbukti berhubungan erat dengan penurunan rasa nyeri, peningkatan daya ingat, memperbaiki nafsu makan, kemampuan seksual, tekanan darah dan pernafasan.

Dari data yang didapat dari Puskesmas Tanjung Karang Kota Mataram tahun 2018 terdapat jumlah wanita menopause sebanyak 2,342 orang, dan yang penderita hipertensi sebanyak 311 orang. Di lingkungan Bendega jumlah wanita menopause sebanyak 120 orang dan yang menderita hipertensi sebanyak 50 orang. Puskesmas Tanjung Karang memiliki binaan pada wanita menopause hanya pemeriksaan kesehatan meliputi pengecekan tekanan darah,dan pemberian obat pada pasien yang sakit.dan belum ada pembinaan lebih lanjut untuk wanita menopause meliputi adanya senam yoga.

\section{HASIL DAN PEMBAHASAN}

Metode pelaksanaan pengabdian kepada masyarakat meliputi beberapa tahapan: 1) survei lokasi, 2) pendataan wanita menopause dan cek tekanan darah, 3) penyuluhan hipertensi \& yoga, 4) pelaksanaan yoga , 5) monitoring dan evaluasi.

1) Survei Lokasi

Survei lokasi dilakukan untuk melakukan pendataan jumlah wanita menopause yang yang ada di lingkungan Bendega wilayah kerja Puskesmas Tanjung Karang. Sementara itu, target dalam pengabdian kepada masyarakat yang dilakukan adalah wanita menopause yang mengalami tekanan darah tinggi / hipertensi dengan kondisi fisik yang baik dan mampu melakukan aktivitas.

2) Pendataan wanita menopause dan cek tekanan darah

Setelah mengetahui jumlah wanita menopause yang ada di lingkungan Bendega wilayah kerja Puskesmas Tanjung Karang, melakukan pengecekan tekanan darah bagi wanita menopause. Wanita menopause yang memiliki tekanan darah sistolik ( $\geq 140 \mathrm{mmHg}$ ) diastolic $(\geq$ $90 \mathrm{mmHg}$ ) akan dijadikan mitra. Pencatatan hasil tekanan darah juga dilakukan pada awal pertemuan sebelum yoga.

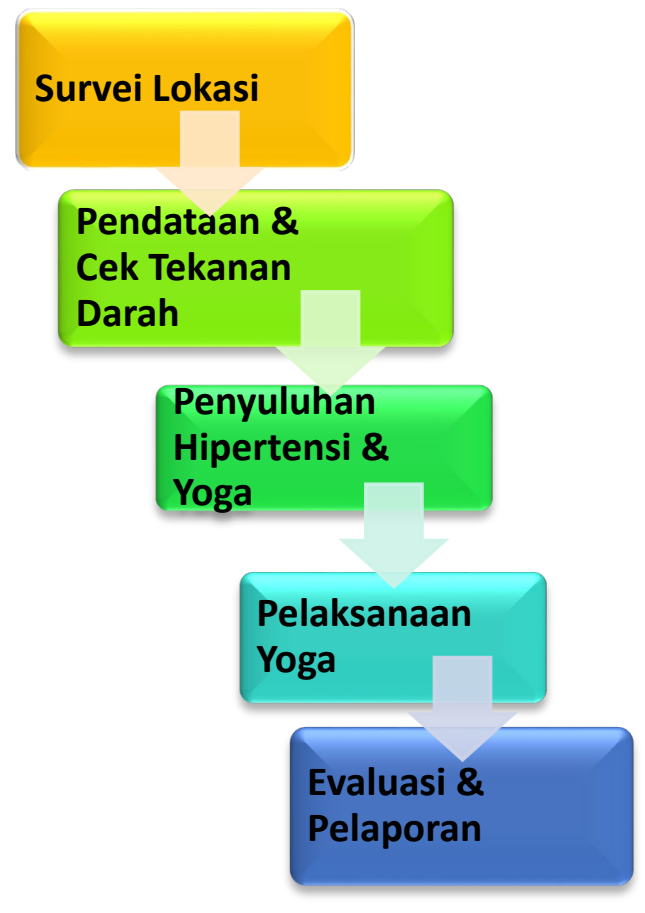

Gambar 1.Tahapan Pelaksanaan Pengabdian Masyarakat

3) Penyuluhan hipertensi \& yoga

Kelas edukasi/sosialisasi dilakukan dengan penyampaian materi mengenai penyakit hipertensi, penyebab hipertensi, komplikasi yang dapat terjadi akibat hipertensi, cara penanganan hipertensi dengan melakukan yoga, pengertian yoga, manfaat yoga, kontraindikasi yoga dengan metode ceramah dan diskusi serta menampilkan video dan media booklet panduan gerakan yoga bagi wanita hipertensi dan menopause.

4) Pelaksanaan Yoga

Pelaksanaan yoga dilaksanakan di Kampus Universitas Bhakti Kencana Fakultas IImu Kesehatan Prodi DIII Kebidanan PSDKU Mataram dan sisanya diharapkan dapat dilakukan oleh peserta kegiatan di rumahnya masing-masing dengan panduan booklet yang diberikan. 
5) Evaluasi \& Pelaporan

Evaluasi kegiatan \& pelaporan dilakukan sebagai bentuk pertanggung jawaban kegiatan dan mengecek kembali hasil kegiatan yoga.

Sasaran kegiatan pengabdian masyarakat adalah wanita menopause (umur 40-60 tahun), mampu melakukan gerakan yoga, hipertensi (tekanan darah sistolik $\geq 140 \mathrm{mmHg}$, diastolik $\geq 90 \mathrm{mmHg}$ ) dan tinggal di wilayah lingkungan Bendega.

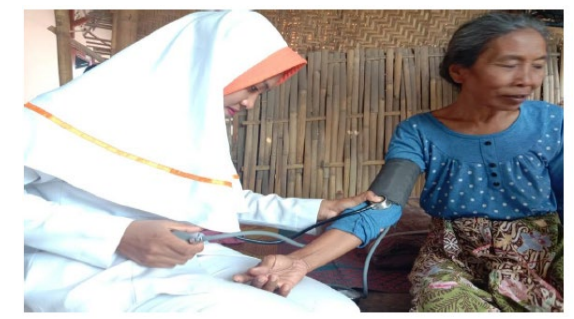

Gambar 2. Pendataan Wanita Menopause Hipertensi

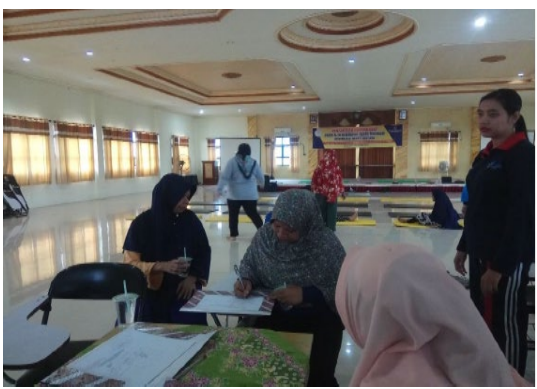

Gambar 3. Registrasi Kegiatan \& Cek Tekanan Darah

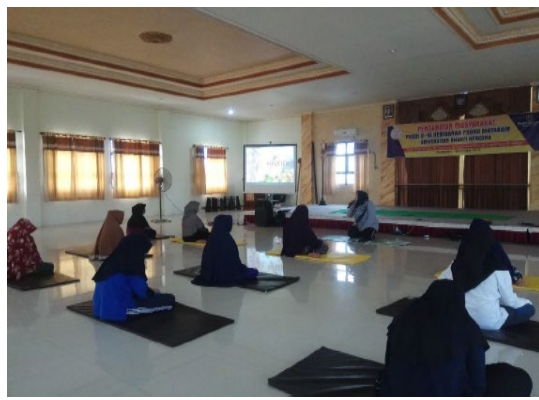

Gambar 4. Penyuluhan Hipertensi pada Wanita Menopause

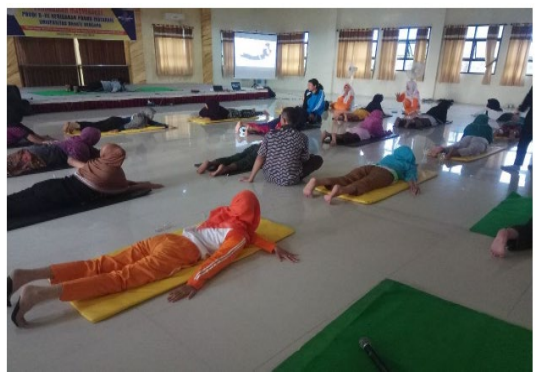

Gambar 5. Praktek Yoga pada Wanita Hipertensi Menopause

Teknik penyuluhan tentang hipertensi dan yoga yaitu dengan menggunakan teknik ceramah, diskusi dan simulasi gerakan yoga dengan media sosialisasi berupa video yang ditampilkan pada layer LCD dan booklet dilanjutkan dengan berlatih yoga. Para peserta diberikan arahan tentang teknik gerakan dan manfaat dari gerakan-gerakan tersebut. Selain itu, mereka diajarkan pola hidup sehat untuk mencegah dan menanggulangi hipertensi.

Setelah dilakukan kegiatan pengabdian masyarakat berupa yoga untuk wanita menopause hipertensi, maka dilakukan evaluasi kegiatan berupa pengecekan kembali tekanan darah peserta setelah pelatihan. Kegiatan ini dilakukan langsung setelah gerakan pendinginan yoga dan mendengarkan musik relaksasi dan meditasi. Didapatkan hasil rata-rata tekanan darah peserta yoga yaitu sebanyak $80 \%$ mengalami penurunan.

Latihan fisik yoga untuk wanita menopause dengan hipertensi telah dilaksanakan di universitas bhakti kencana mataram dari bulan November - Desember 2019. Jumlah peserta yang mengikuti kegiatan berjumlah 20 ibu menopause dengan hipertensi. Kegiatan dilaksanakan di kampus bhakti kencana mataram pada tanggal 7 Desember 2019. Rangkaian kegiatan yaitu sebelum melakukan yoga, ibu - ibu diberikan informasi mengenai penyakit hipertensi dan aktifitas yoga dalam usaha menurunkan tekanan darah tinggi. Setelah memberikan edukasi, praktik yoga dilaksanakan secara bersama . hasil pengukuran tekanan darah sebelum dan setelah yoga dengan rata-rata penurunan $20 \mathrm{mmHg}$ untuk sistol dan $10 \mathrm{mmHg}$ untuk diastole.

\section{SIMPULAN DAN SARAN}

Setelah dilakukan kegiatan pengabdian masyarakat berupa yoga untuk wanita menopause hipertensi, maka dilakukan evaluasi kegiatan berupa pengecekan kembali tekanan darah peserta setelah latihan fisik yoga. Didapatkan hasil rata-rata tekanan darah peserta yoga yaitu sebagian besar menjadi turun. Wanita menopause yang datang pada saat pelaksanaan latihan yoga sudah dapat mengulangi kembali teknik gerakan yoga yang disampaikan oleh narasumber. Kegiatan latihan fisik yoga pada wanita menopause hipertensi memberikan edukasi agar tercipta kesadaran untuk menurunkan hipertensi. Bagi wanita menopause disarankan agar tetap melakukan latihan fisik yoga untuk menurunkan hipertensi.

\section{UCAPAN TERIMA KASIH}

Terima kasih kami ucapkan kepada LPPM Universitas Bhakti Kencana yang telah mendanai kegiatan pengabdian ini. Terima kasih kepada masyarakat Bendega dan seluruh 
pihak yang terlibat dalam penyelenggaraan kegiatan ini.

\section{DAFTAR RUJUKAN}

Andarini. (2012). Terapi Nutrisi Pasien Usia Lanjut yang Dirawat di Rumah Sakit. Di dalam: Harjodisastro D, Syam AF, Sukrisman L, editor. Dukungan Nutrisi pada Kasus Penyakit Dalam. Jakarta: Departemen Ilmu Penyakit Dalam Fakultas Kedokteran UI.

Anggara Dwi, F H dan Prayitno N. (2013). Faktor-faktor yang Berhubungan dengan Tekanan Darah di Puskesmas Telaga Murni Cikarang Barat. Jakarta: Program Studi Kesehatan Masyarakat STIKES MH. Thamrin. Jurnal IImiah Kesehatan. Vol 5/ No. 1

Dinata, Windo Wiria. (2015). Menurunkan Tekanan Darah Pada Lansiamelalui Senam Yoga. JORPRES (Jurnal Olahraga Prestasi), 11(2).

Group W. (1995). The World Health Organization quality of life assessment (WHOQOL): position paper from the World Health Organization. Social science \& medicine. 41(10), 1403-9

Kesehatan B. (2014). Panduan Praktis Prolanis (Program Pengelolaan Penyakit Kronis). Jakarta: BPJS Keseharan.

Kokkinos, PF. (2009). Effects of Regular Exercise on Blood Pressure and Left Ventricular Hypertrophy in AfricanAmerican Man with Severe Hypertension. N Engl J Med. Vol 333 pp. 1462-7.

Kontesa M, refelinda Y, (2013). Efektifitas senam yoga terhadap produksi asi ibu menyusui di kenagarian jawi jawi wilayah kerja puskesmas talang , tahun 2013

Muchtadi, D. (2009). Gizi Anti Penuaan Dini. ALFABETA. Bandung : 79-81.

Puskesmas tanjung Karang. (2018) Data wanita menopause hipertensi : .Kota Mataram

Riset Kesehatan Dasar (Riskesdas) (2018). Badan Penelitian dan Pengembangan Kesehatan Kementerian RI tahun 2018. http://www.depkes.go.id/resources/do wnload/infoterkini/materi_rakorpop_20 18/Hasil\%20Riskesdas\%202018.pdf Diakses : Agustus 2018

Saputra, M., (2011). Depresi Pada Wanita Menopause dan Hubungannya dengan Kualitas Hidup. Tesis. Bagian Obstetri dan Ginekologi RSUP Dr. M. Djamil: Fakultas Kedokteran Universitas Andalas.
Volume 3, Nomor 2, Mei 2020. p-ISSN : 2614-5251 e-ISSN : 2614-526X

Sindhu, (2011). Latihan Yoga. http://download.portalgaruda.org/article .php. Diakses Lansia Penderita Hipertensi di Dusun Niten Nogotirto Gamping Sleman Yogyakarta. digilib.unisayogya. ac.id. Diakses 11/05/2018.

Visvanathan K, Gallicchio, L.,Schilling, C.,Babus, J.K., Lewis, L.M., Miller, S.R., Zacur, H., and Flaws, J.A. (2005). Cytochormone gene polymorphism, serum estrogens, and hot flushes in midlife women. 2008; Obstet Gynecol vol 106.

Williams R.E, Kaliliani, L., DiBendetti, D.B., Zhou, X., Clark, . (2007). Healthcare seeking and treatment for monopousal symptoms in the United States. Maturitas. 